\title{
Influence of Heavy Metals on Seed Germination and Early Seedling Growth in Crambe abyssinica, a Potential Industrial 0il Crop for Phytoremediation
}

\author{
Jin Hu', Zhaohui Deng², Bin Wang1, Yuan Zhi', Bingxue Pei', Guangyu Zhang1, \\ Mingdan Luo1, Banglian Huang1, Wenhua Wu ${ }^{1 *}$, Bangquan Huang1 \\ ${ }^{1}$ Hubei Collaborative Innovation Center for Green Transformation of Bio-Resources, College of Life Science, \\ Hubei University, Wuhan, China \\ ${ }^{2}$ Vocational and Technical College of Anshun, Anshun, China \\ Email: $1305142468 @ q q . c o m$
}

Received 12 December 2014; accepted 25 December 2014; published 15 January 2015

Copyright (C) 2015 by authors and Scientific Research Publishing Inc.

This work is licensed under the Creative Commons Attribution International License (CC BY).

http://creativecommons.org/licenses/by/4.0/

(c) (i) Open Access

\section{Abstract}

The influence of essential ( $\mathrm{Cu}, \mathrm{Ni}$ and $\mathrm{Zn}$ ) and non-essential heavy metals $(\mathrm{Hg}, \mathrm{Cr}, \mathrm{Pb}$ and $\mathrm{Cd})$ on seed germination and early seedling growth in industrial oil crop Crambe abyssinica was evaluated under laboratory conditions. Our results indicated that among the 7 heavy metals tested only $\mathrm{Cu}$ and $\mathrm{Hg}$ significantly $(\mathrm{P}<0.01)$ decreased Crambe seed germination in a dose-dependent manner at higher concentrations while certain $\mathrm{Cr}$ concentrations significantly increased the seed germination $(P<0.05)$. All the 7 heavy metals decreased significantly relative root length, shoot length and fresh seedling weight in a dose-dependent manner $(P<0.01)$. The heavy metals except $\mathrm{Ni}$ decreased relative root length first, then shoot length or fresh seedling weight, and finally seed germination. Ni seemed to influence the relative fresh seedling weight first, then shoot length, root length and finally seed germination at lower concentrations, but the decrease in relative root length became faster when the $\mathrm{Ni}$ concentrations were increased. Our results indicated that Crambe is tolerant or moderately tolerant to the heavy metals tested except $\mathrm{Ni}$ and can be improved for phytoremediation of soils contaminated by heavy metals.

\section{Keywords}

Crambe abyssinica, Heavy Metal, Seed Germination, Early Seedling Growth, Phytoremediation

\footnotetext{
${ }^{*}$ Corresponding author.
}

How to cite this paper: Hu, J., et al. (2015) Influence of Heavy Metals on Seed Germination and Early Seedling Growth in Crambe abyssinica, a Potential Industrial Oil Crop for Phytoremediation. American Journal of Plant Sciences, 6, 150-156. 


\section{Introduction}

Heavy metals such as $\mathrm{Cu}, \mathrm{Zn}$ and $\mathrm{Ni}$ are essential micronutrients for plants, but are toxic at high concentrations. Other heavy metals like $\mathrm{Hg}, \mathrm{Cd}, \mathrm{Cr}$ and $\mathrm{Pb}$ present in soil and water naturally or as contaminants from human activities can cause bioaccumulation affecting the entire ecosystem and pose harmful health consequences in all life forms [1]. Unlike organic pollutants, heavy metals cannot be chemically degraded or biodegraded by microorganisms [2]. One alternative biological approach to deal with this problem is phytoremediation-the use of plants to remove, destroy or sequester hazardous substances from environment. It has become a topical research field in the last decades because it offers advantages of being safe, in situ, nondestructive and potentially cheap compared with traditional remediation techniques [3]-[8]. Application of phytoextraction can reduce phytoavailable metals in the soil and thereby diminish toxic metal contents in agricultural products. Some famous hyperaccumulators have been deeply researched such as Cd/Zn hyperaccumulator Thlaspi caerulescens [9] [10], Sedum alfredii [11] [12], As hyperaccumulator Pteris vittata [13] [14], Cd hyperaccumulator Solanum nigrum [15], Arabidopsis halleri [16], Athyrium yokoscense and a number of ferns belonging to the genus Pteris [17]. However, these hyperaccumulators are of very little economic value, making it difficult for them to be used in phytoremediation.

Crambe abyssinica is a Cruciferae member that is a promising industrial oil crop since it shows high seed yield potential and high-erucic acid content in its seed oil [18]-[20]. The erucic acid content in Crambe seed oil was further increased to over 70\% by genetic engineering [21]. Crambe can be developed into a relatively "safe" GMO industrial oil crop for phytoremediation with both environmental as well as economic values since it does not cross with the edible double-low canola [22]. Previous studies indicated that Crambe was not only highly tolerant to As and Cd, but also accumulated significantly higher levels of As than other Brassica species [23] [24]. The present study was made to determine the influence of essential ( $\mathrm{Cu}, \mathrm{Ni}$ and $\mathrm{Zn}$ ) and non-essential metal ions ( $\mathrm{Pb}, \mathrm{Cd}, \mathrm{Cr}$ and $\mathrm{Hg}$ ) on Crambe seed germination, early seedling growth and the potential of using Crambe for phytoremediation of soils contaminated by heavy metals.

\section{Materials and Methods}

Healthy Crambe seeds were inoculated on sand cultures with different concentrations of heavy metals. The heavy metals except $\mathrm{Pb}$ were dissolved in liquid MS without sugar and organic components. $\mathrm{Pb}$ was dissolved in $\mathrm{ddH}_{2} \mathrm{O}$ to avoid precipitation. Different concentrations of heavy metals were prepared from $\mathrm{CuSO}_{4} \cdot 5 \mathrm{H}_{2} \mathrm{O}$, $\mathrm{ZnSO}_{4} \cdot 7 \mathrm{H}_{2} \mathrm{O}, \mathrm{NiSO}_{4} \cdot 6 \mathrm{H}_{2} \mathrm{O}, \mathrm{K}_{2} \mathrm{Cr}_{2} \mathrm{O}_{7}, \mathrm{~Pb}\left(\mathrm{NO}_{3}\right)_{2}, \mathrm{HgCl}_{2}$ and $\mathrm{CdCl}_{2} \cdot 2.5 \mathrm{H}_{2} \mathrm{O}$. Seed germination rates were scored 4 days after inoculation and root length, shoot length and fresh seedling weight were measured 7 - 8 days after seed inoculation. The relative seed germination, root length, shoot length and fresh seedling weight were calculated as that of treatments with heavy metals divided by that of controls. The incubation temperature was set at $25^{\circ} \mathrm{C}$ with a 16-hr photo period under $2000 \mathrm{~lx}$. The experiment was arranged in a completely randomized design with three replicates, each replicate with about 50 Crambe seeds. Variance analyses and multiple comparisons were carried out on SPSS 19.0.

\section{Results and Discussion}

Figure 1 indicated that among the 7 heavy metals tested only higher concentrations of $\mathrm{Cu}(0.7 \mathrm{mM}$ or 44.8 $\mathrm{mg} \cdot \mathrm{L}^{-1}$ and above) and $\mathrm{Hg}\left(0.3 \mathrm{mM}\right.$ or $60.3 \mathrm{mg} \cdot \mathrm{L}^{-1}$ and above $)$ decreased Crambe seed germination significantly $(\mathrm{P}<0.01)$ in a dose-dependent manner, while certain concentrations of $\mathrm{Cr}$ significantly increased seed germination $(\mathrm{P}<0.05)$. Figures $2-4$ indicated that all the 7 heavy metals tested significantly decreased Crambe relative root length, shoot length and fresh seedling weight in a dose-dependent manner. Heavy metals except $\mathrm{Ni}$ decreased relative root length first, then shoot length or fresh seedling weight, and finally seed germination. Ni seemed to influence relative fresh seedling weight first, then shoot length, root length and finally seed germination at lower concentrations, but the decrease in relative root length became faster when Ni concentrations were increased.

\subsection{The Influence of $\mathrm{Cu}$}

Most studies indicated that $\mathrm{Cu}$ significantly decreased seed germination. With $10 \mu \mathrm{M} \mathrm{Cu}$ treatment, wheat and rice seed germination was reduced by more than $35 \%$ and $60 \%$, respectively [25]. In alfalfa $40 \mathrm{mg} \cdot \mathrm{L}^{-1} \mathrm{Cu}$ inhi- 


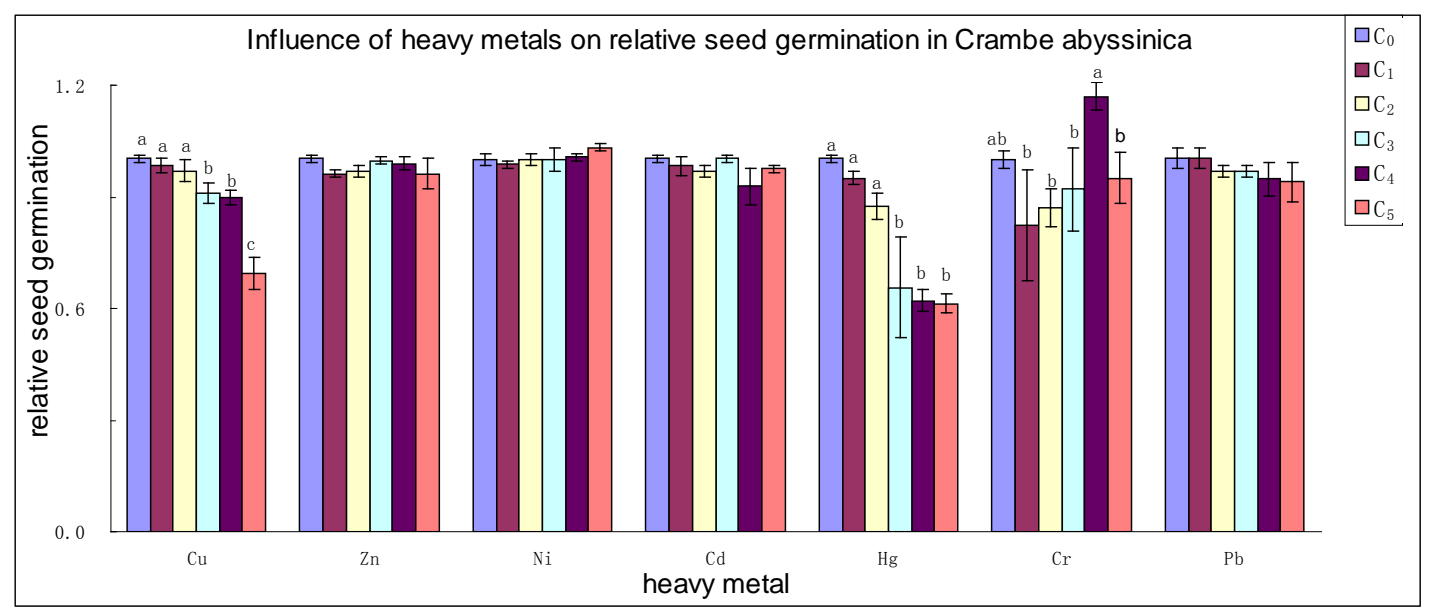

Figure 1. Influence of heavy metals on relative seed germination in Crambe abyssinica. Note: $\mathrm{C}_{0}=$ without heavy metal; With $\mathrm{Cu}, \mathrm{C}_{1}=0.3 \mathrm{mM}, \mathrm{C}_{2}=0.5 \mathrm{mM}, \mathrm{C}_{3}=0.7 \mathrm{M}, \mathrm{C}_{4}=0.9 \mathrm{M}, \mathrm{C}_{5}=1.2 \mathrm{mM}$; with $\mathrm{Zn}, \mathrm{C}_{1}=0.10 \mathrm{mM}, \mathrm{C}_{2}=$ $0.40 \mathrm{mM}, \mathrm{C}_{3}=0.55 \mathrm{mM}, \mathrm{C}_{4}=0.70 \mathrm{mM}, \mathrm{C}_{5}=0.85 \mathrm{mM}$; with $\mathrm{Cr}, \mathrm{C}_{1}=0.05 \mathrm{mM}, \mathrm{C}_{2}=0.10 \mathrm{mM}, \mathrm{C}_{3}=0.20 \mathrm{mM}$, $\mathrm{C}_{4}=0.40 \mathrm{mM}, \mathrm{C}_{5}=0.80 \mathrm{mM}$; with Ni, $\mathrm{C}_{1}=0.4 \mu \mathrm{M}, \mathrm{C}_{2}=0.6 \mu \mathrm{M}, \mathrm{C}_{3}=0.8 \mu \mathrm{M}, \mathrm{C}_{4}=1.0 \mu \mathrm{M}, \mathrm{C}_{5}=1.2 \mu \mathrm{M}$; with $\mathrm{Pb}, \mathrm{C}_{1}=0.8 \mathrm{mM}, \mathrm{C}_{2}=3.2 \mathrm{mM}, \mathrm{C}_{3}=4.0 \mathrm{mM}, \mathrm{C}_{4}=5.0 \mathrm{mM}, \mathrm{C}_{5}=5.5 \mathrm{mM}$; with $\mathrm{Hg}, \mathrm{C}_{1}=0.1, \mathrm{C}_{2}=0.2 \mathrm{mM}, \mathrm{C}_{3}=$ $0.3 \mathrm{mM}, \mathrm{C}_{4}=0.4 \mathrm{mM}, \mathrm{C}_{5}=0.5 \mathrm{mM}$; with Cd, $\mathrm{C}_{1}=0.10 \mathrm{mM}, \mathrm{C}_{2}=0.20 \mathrm{mM}, \mathrm{C}_{3}=0.30 \mathrm{mM}, \mathrm{C}_{4}=0.38 \mathrm{mM}, \mathrm{C}_{5}=$ $0.46 \mathrm{mM}$. Figures with same letters were not significant at 0.05 level.

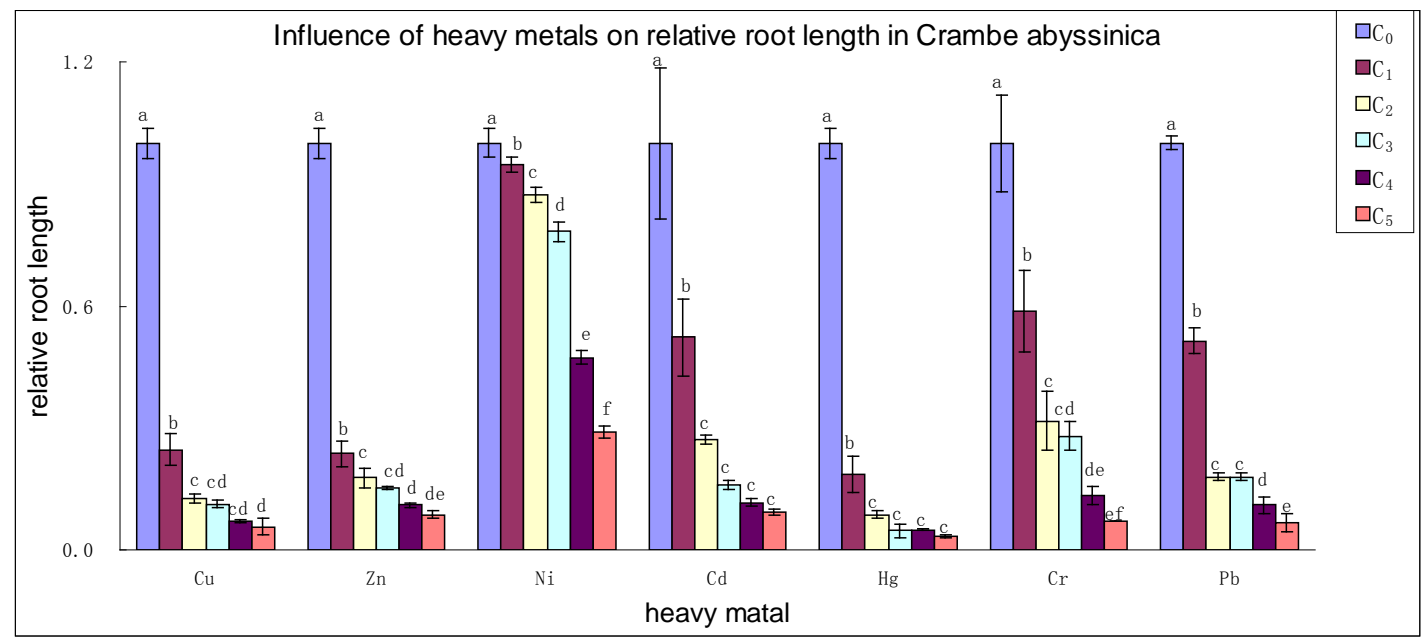

Figure 2. Influence of heavy metals on relative root length in Crambe abyssinica. Note: Explanations are same as in Figure 1.

bited significantly seed germination by 39.0\% [26]. In our experiment, only higher Cu concentration $(0.7 \mathrm{mM}$ or $44.8 \mathrm{mg} \cdot \mathrm{L}^{-1}$ and above) decreased Crambe seed germination significantly $(\mathrm{P}<0.01) .0 .7 \mathrm{mM}$ Cu decreased Crambe seed germination by $9.30 \%$ and $1.2 \mathrm{mM} \mathrm{Cu}$ by $30.90 \%$ (Figure 1), suggesting that Crambe seed germination is moderately tolerant to $\mathrm{Cu}$. Taylor and Foy [27] found $30 \mu \mathrm{M} \mathrm{Cu}$ enough for reducing growth of wheat (Triticum aestivum L.) by 50\%, whereas Wheeler et al. [28] reported only $0.5 \mu \mathrm{M} \mathrm{Cu}$ was required for a $50 \%$ growth reduction in the same species. In Arabidopsis $0.2 \mathrm{mM} \mathrm{Cu}$ inhibited seedling growth by about $60 \%$ [29]. In our experiment, $0.3 \mathrm{mM} \mathrm{Cu}\left(19.2 \mathrm{mg} \cdot \mathrm{L}^{-1}\right.$ ) decreased relative root length by $75.33 \%$ (Figure 2), shoot length by $29.44 \%$ (Figure 3 ) and fresh seedling weight by $22.26 \%$ (Figure 4), suggesting that Crambe is moderately tolerant to $\mathrm{Cu}$ regarding early seedling growth.

\subsection{The Influence of $\mathrm{Zn}$}

In alfalf $40 \mathrm{mg} \cdot \mathrm{L}^{-1} \mathrm{Zn}$ did not significantly reduce seed germination [26]. In wheat seed germination was com- 


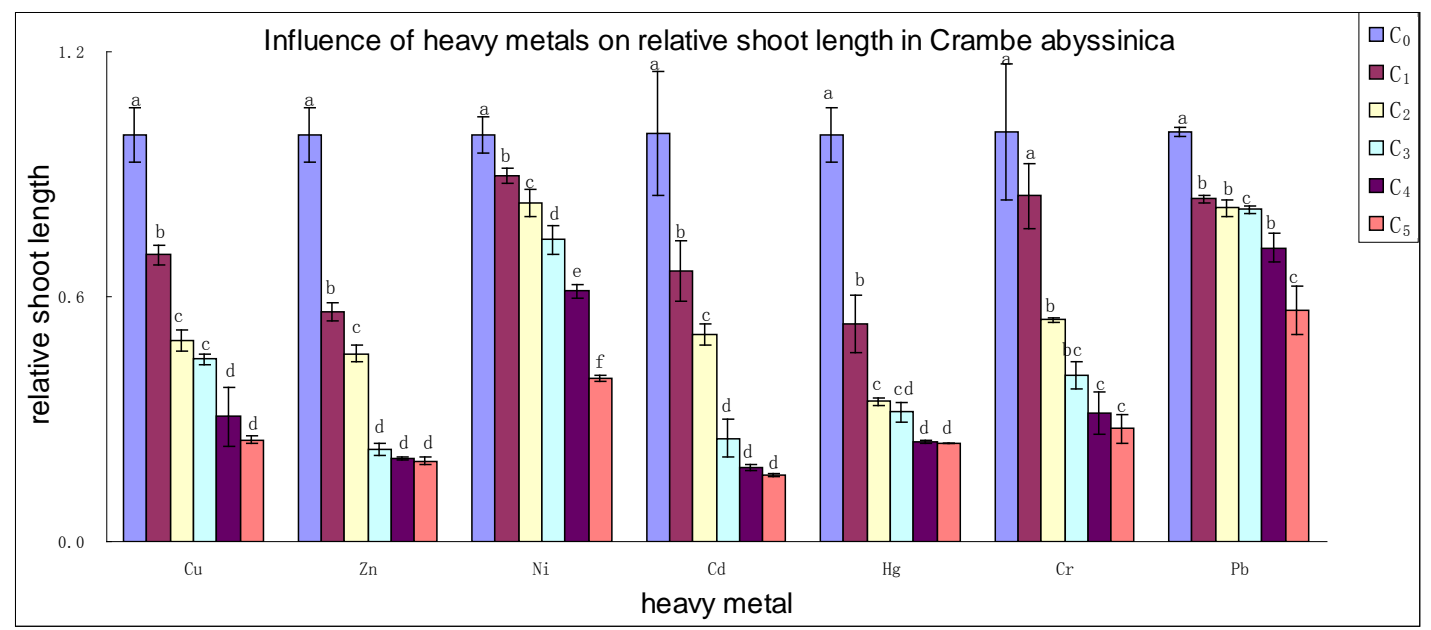

Figure 3. Influence of heavy metals on relative shoot length in Crambe abyssinica. Note: Explanations are same as in Figure 1.

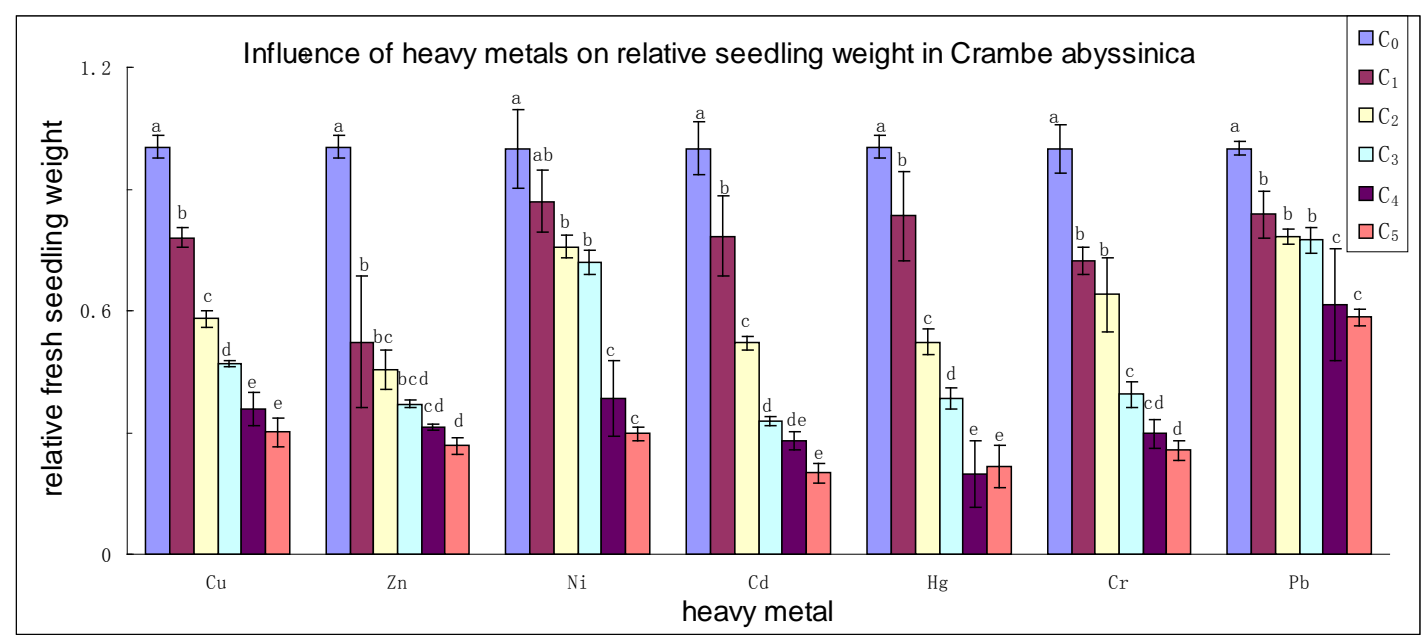

Figure 4. Influence of heavy metals on relative fresh seedling weight in Crambe abyssinica. Note: Explanations are same as in Figure 1.

pletely inhibited at $10 \mathrm{mg} \cdot \mathrm{L}^{-1} \mathrm{Zn}$ [30]. Our results indicated that even $0.85 \mathrm{mM}\left(55.25 \mathrm{mg} \cdot \mathrm{L}^{-1}\right) \mathrm{Zn}$ did not significantly decrease Crambe seed germination (Figure 1), suggesting that Crambe seed germination is tolerant to $\mathrm{Zn}$. In Eruca the root length was decreased by $31.54 \%$ and shoot length by $28.89 \%$ at $50 \mathrm{mg} \cdot \mathrm{L}^{-1} \mathrm{Zn}$ [31]. In hyperaccumulator species Thlaspi goesingense, Zn concentration required for $50 \%$ inhibition of root growth was higher than $500 \mu \mathrm{M}$, while in Arabidopsis thaliana Zn concentration required for a 50\% inhibition of root growth was $98 \mu \mathrm{M}$ [32]. In our experiment, $\mathrm{Zn}$ inhibited root length by about 76.33\% (Figure 2), shoot length by $43.48 \%$ (Figure 3 ) and fresh seedling weight by $47.84 \%$ (Figure 4 ) at $0.1 \mathrm{mM}$ concentration $\left(6.5 \mathrm{mg} \cdot \mathrm{L}^{-1}\right.$ ), suggesting that Crambe is only moderately tolerant to $\mathrm{Zn}$ regarding early seedling growth.

\subsection{The Influence of $\mathrm{Ni}$}

In alfalf, $40 \mathrm{mg} \cdot \mathrm{L}^{-1} \mathrm{Ni}$ inhibited significantly seed germination by $24.0 \%$ [26]. In maize at $50 \mathrm{mg} \cdot \mathrm{L}^{-1} \mathrm{Ni}$ seed germination was decreased only by $11.70 \%$ [33]. In our experiment Crambe seed germination was not significantly influenced by Ni concentrations tested in this study $\left(0.4-1.2 \mu \mathrm{M}\right.$ or $23.6-70.8 \mu \mathrm{g} \cdot \mathrm{L}^{-1}$, Figure 1$)$, but our preliminary study indicated that Crambe root growth was completely inhibited at over $80 \mu \mathrm{M}$ Ni (data not shown). In maize, $10 \mu \mathrm{M} \mathrm{Ni}$ decreased root length by $19.44 \%$ and shoot length by $39.13 \%$ [33]. In hyperaccumulator species Thlaspi goesingense the Ni concentration required for $50 \%$ inhibition of root growth was higher 
than $500 \mu \mathrm{M}$, while in Arabidopsis thaliana the Ni concentration required for $50 \%$ inhibition of root growth was $80 \mu \mathrm{M}$ [32]. In our experiment $0.4 \mu \mathrm{M}$ Ni significantly decreased root length by $5.33 \%$ and $1.2 \mu \mathrm{M}$ Ni decreased root length by 71\% (Figure 2), shoot length by 60\% (Figure 3) and fresh seedling weight by 73.42\% (Figure 4), indicating that early Crambe early seedling growth is quite sensitive to $\mathrm{Ni}$.

\subsection{The Influence of Cd}

In wheat seed germination was decreased by $60 \%$ at $10 \mathrm{mg} \cdot \mathrm{L}^{-1} \mathrm{Cd}$ [30]. In Sinapis arvensis $1000 \mu \mathrm{M} \mathrm{Cd}$ significantly decreased the seed germination by 5.6\% [34]. In our experiment Crambe seed germination was not significantly affected by all Cd concentrations $(0.10-0.46 \mathrm{mM})$ tested in this study (Figure 1$)$, suggesting that Crambe seed germination is tolerant to Cd. In Eruca the root length was decreased by $27.69 \%$ and shoot length by $43.78 \%$ at $50 \mathrm{mg} \cdot \mathrm{L}^{-1} \mathrm{Cd}$ [31]. In Sinapis arvensis the root length was decreased significantly by $92.62 \%$, shoot length by $56.31 \%$ and fresh seedling weight by $49.69 \%$ at $150 \mu \mathrm{M} \mathrm{Cd}$ [34]. In Arabidopsis halleri the shoot and root growth was inhibited by 82 and $74 \%$ respectively at $100 \mu \mathrm{M} \mathrm{Cd}$ [35]. In Arabidopsis thaliana the $\mathrm{Cd}$ concentration required for $50 \%$ inhibition of root growth was only $38 \mu \mathrm{M}$ [32]. In our experiment $0.1 \mathrm{mM}$ Cd (11.2 $\mathrm{mg} \cdot \mathrm{L}^{-1}$ ) decreased Crambe root length by $47.67 \%$ (Figure 2), shoot length by 33.67\% (Figure 3), fresh seedling weight by $13 \%$ (Figure 4) without visible chlorosis, suggesting that Crambe is moderately tolerant to Cd regarding early seedling growth.

\subsection{The Influence of $\mathrm{Hg}$}

In Brassica juncea, treatment with $2 \mu \mathrm{M} \mathrm{Hg}$ for $24 \mathrm{~h}$ inhibited root growth by about $80 \%$ [36]. In Brassica napus the biomass was decreased by about $60 \%$ at $10 \mathrm{mg} \cdot \mathrm{L}^{-1} \mathrm{Hg}$ [37]. In our experiment $\mathrm{Hg}$ only significantly decreased Crambe seed germination at $0.3 \mathrm{mM}\left(60.3 \mathrm{mg} \cdot \mathrm{L}^{-1}\right)$ by $34.66 \%$ (Figure 1). Crambe root length was decreased by $81.33 \%$ (Figure 2), shoot length by 46.34\% (Figure 3) and fresh seedling weight by 16.94\% (Figure 4) at $0.1 \mathrm{mMHg}\left(20.1 \mathrm{mg} \cdot \mathrm{L}^{-1}\right)$, suggesting that Crambe early seedling growth is only moderately tolerant to Hg.

\subsection{The Influence of $\mathrm{Cr}$}

In alfalf, 40 ppm Cr inhibited significantly seed germination by 54.0\% [26]. In wheat seed germination was decreased by $80 \%$ at $10 \mathrm{mg} \cdot \mathrm{L}^{-1} \mathrm{Cr}$ [30]. In our experiment Crambe seed germination was not significantly decreased by $\mathrm{Cr}$ concentrations tested $\left(0.05-0.80 \mathrm{mM}\right.$ or $\left.2.6-41.6 \mathrm{mg} \cdot \mathrm{L}^{-1}\right)$, suggesting that Crambe seed germination is tolerant to $\mathrm{Cr}$ (Figure 1). Zulfiqar et al. [38] reported that Crambe fresh weight of plants was decreased moderately at $100 \mu \mathrm{M} \mathrm{K}_{2} \mathrm{CrO}_{4}$, whereas at $150 \mu \mathrm{M} \mathrm{K}_{2} \mathrm{CrO}_{4}$ there was a significant reduction in biomass with no symptoms of severe cellular damage, but at higher concentration $(200$ and $250 \mu \mathrm{M})$, plant showed chlorosis and visible necrosis on leaves. In our experiment Crambe root length was decreased by 41.33\% (Figure 2), shoot length by $15.66 \%$ (Figure 3) and fresh seedling weight by $27.67 \%$ (Figure 4) at $0.05 \mathrm{mM}$ Cr, suggesting that Crambe is only moderately tolerant to Cr regarding early seedling growth.

\subsection{The Influence of $\mathrm{Pb}$}

In Sinapis arvensis, seed germination was decreased significantly by $6.17 \%$ at $1200 \mu \mathrm{M} \mathrm{Pb}$ [34]. In our experiment Crambe seed germination was not significantly decreased by the Pb concentrations tested (0.8 - $5.5 \mathrm{mM})$, suggesting that Crambe seed germination is tolerant to $\mathrm{Pb}$ (Figure 1). In Eruca the root length was decreased by $20.0 \%$ and shoot length by $23.78 \%$ at $50 \mathrm{mg} \cdot \mathrm{L}^{-1} \mathrm{~Pb}$ [31]. In Sinapis arvensis, root length was decreased significantly by $66.46 \%$, shoot length by $38.62 \%$ and fresh seedling weight by $33.33 \%$ at $300 \mu \mathrm{M} \mathrm{Pb}$ [34]. In our experiment Crambe root growth was decreased only by $48.67 \%$ (Figure 2), shoot length by 16.33\% (Figure 3), and fresh seedling weight by $16.33 \%$ (Figure 4) at $0.8 \mathrm{mM} \mathrm{Pb}\left(165.6 \mathrm{mg} \cdot \mathrm{L}^{-1}\right)$, suggesting that Crambe is quite tolerant to $\mathrm{Pb}$.

\section{Conclusion}

Our results indicate that Crambe is tolerant or moderately tolerant to $\mathrm{Cu}, \mathrm{Zn}, \mathrm{Hg}, \mathrm{Cr}, \mathrm{Pb}$ and $\mathrm{Cd}$ but sensitive to Ni regarding seed germination and seedling growth and Crambe can be improved as a promising industrial oil crop for phytoremediation of soils contaminated by heavy metals. 


\section{Acknowledgements}

This work was supported by funds from Science and Technology Department of Hubei Province; Huangshi science and technology bureau; Key Laboratory Biology and Genetic Improvement of Oil Crops, Ministry of Agriculture, China; National Natural Science Foundation of China (30771382, 30671334, 30971807, 31201238); an European Committee 7th Framework Programme (ICON, 211400) and Swedish Research Links project.

\section{References}

[1] Munzuroglu, O. and Geckil, H. (2002) Effects of Metals on Seed Germination, Root Elongation, and Coleoptile and Hypocotyls Growth in Triticum aestivum and Cucumis sativus. Archives of Environment Contamination and Toxicology, 43, 203-213. http://dx.doi.org/10.1007/s00244-002-1116-4

[2] Kramer, U. (2005) Phytoremediation: Novel Approaches to Cleaning up Polluted Soils. Current Opinion in Biotechnology, 16, 133-141. http://dx.doi.org/10.1016/j.copbio.2005.02.006

[3] Cunningham, S.D. and Ow, D.W. (1996) Promises and Prospects of Phytoremediation. Plant Physiology, 110, 715719.

[4] Salt, D.E., Smith, R.D. and Raskin, I. (1998) Phytoremediation. Annual Review of Plant Physiology and Plant Molecular Biology, 49, 643-668. http://dx.doi.org/10.1146/annurev.arplant.49.1.643

[5] Mitch, M.L. (2002) Phytoextration of Toxic Metals: A Review of Biological Mechanism. Journal of Environment Quality, 31, 109-120. http://dx.doi.org/10.2134/jeq2002.0109

[6] McGrath, S.P. and Zhao, F.J. (2003) Phytoextraction of Metals and Metalloids from Contaminated Soils. Current Opinion in Biotechnology, 14, 277-282. http://dx.doi.org/10.1016/S0958-1669(03)00060-0

[7] Glick, B.R. (2003) Phytoremediation: Synergistic Use of Plants and Bacteria to Clean up the Environment. Biotechnology Advances, 21, 383-393. http://dx.doi.org/10.1016/S0734-9750(03)00055-7

[8] Pulford, I.D. and Watson, C. (2003) Phytoremediation of Heavy Metal-Contaminated Land by Tree-A View. Environment International, 29, 529-540. http://dx.doi.org/10.1016/S0160-4120(02)00152-6

[9] Baker, A.J.M., McGrath, S.P., Reeves, R.D. and Smith, J.A.C. (2000) Metal Hyperaccumulator Plants: A Review of the Ecology and Physiology of a Biochemical Resource for Phytoremediation of Metal-Polluted Soils. In: Terry, N. and Bauelos, G., Eds., Phytoremediation of Contaminated Soil and Water, Lewis Publishers, Florida, 85-107.

[10] Liu, Y., G., Zhang, Y.X. and Chai, T.Y. (2011) Phytochelatin Synthase of Thlaspi caerulescens Enhanced Tolerance and Accumulation of Heavy Metals When Expressed in Yeast and Tobacco. Plant Cell Reports, 30, 1067-1076. http://dx.doi.org/10.1007/s00299-011-1013-2

[11] Yang, X.E., Long, X.X., Ye, H.B., He, Z.L., Stoffella, P.J. and Calvert, D.V. (2004) Cadmium Tolerance and Hyperaccumulation in a New Zn-Hyperaccumulating Plant Species (Sedum alfredii Hance). Plant and Soil, 259, 181-189. http://dx.doi.org/10.1023/B:PLSO.0000020956.24027.f2

[12] Li, T.Q., Yang, X.E., Jin, X.F., He, Z.L., Stoffella, P.J. and Hu, Q.H. (2005) Root Responses and Metal Accumulation in Two Contrasting Ecotypes of Sedum alfredii Hance under Lead and Zinc Toxic Stress. Journal of Environment Science and Health, Part A. Toxic and Hazardous Substance Environmental Engineering, 40, 1081-1096.

[13] Ma, L.Q., Komar, K.M., Tu, C., Zhang, W.H., Cai, Y. and Kennelley, E.D. (2001) A Fern That Hyperaccumulates Arsenic: A Hardy, Versatile, Fast-Growing Plant Helps to Remove Arsenic from Contaminated Soils. Nature, 479, 579. http://dx.doi.org/10.1038/35054664

[14] Mathews, S., Rathinasabapathi, B. and Ma, L.Q. (2011) Uptake and Translocation of Arsenite by Pteris vittala L.: Effects of Glycerol, Antimonite and Silver. Environmental Pollution, 159, 3490-3495. http://dx.doi.org/10.1016/j.envpol.2011.08.027

[15] Yang, C.J., Zhou, Q.X., Wei, S.H., Hu, Y.H. and Bao, Y.Y. (2011) Chemical-Assisted Phytoremediation of Cd-PAHs Contaminated Soils Using Solanum nigrum L. International Journal of Phytoremediation, 13, 818-833. http://dx.doi.org/10.1080/15226514.2010.532179

[16] Kupper, H., Lombi, E., Zhao, F.J. and McGrath, S.P. (2000) Cellular Compartmentation of Cadmium and Zinc in Relation to Other Elements in the Hyperaccumulator Arabidopsis halleri. Planta, 212, 75-84. http://dx.doi.org/10.1007/s004250000366

[17] Morishirta, T. and Boratynski, K. (1992) Accumulation of Cd and Other Metals in Organs of Plants Growing around Metal Smelters in Japan. Soil Science and Plant Nutrition, 38, 781-785. http://dx.doi.org/10.1080/00380768.1992.10416712

[18] Carlson, K.D., Gardner, J.C., Anderson, V.L. and Hanzel, J.J. (1996) Crambe: New Crop Success. In: Janick, J., Ed., Progress in New Crops, ASHS Press, Alexandria, 306-322. 
[19] Wang, Y.P., Tang, J.S., Chu, C.Q. and Tian, J. (2000) A Preliminary Study on the Introduction and Cultivation of Crambe abyssinica in China, an Oil Plant for Industrial Uses. Industrial Crop Production, 12, 47-52. http://dx.doi.org/10.1016/S0926-6690(99)00066-7

[20] Huang, B., Yang, Y., Luo, T., Wu, S., Du, X., Cai, D., Loo, E.N.V. and Huang, B. (2013) Correlation, Regression and Path Analyses of Seed Yield Components in Crambe abyssinica, a Promising Industrial Oil Crop. American Journal of Plant Sciences, 4, 42-47. http://dx.doi.org/10.4236/ajps.2013.41007

[21] Li, X., van Loo, E.N., Gruber, J., Fan, J., Guan, R., Frentzen, M., Stymne, S. and Zhu, L.H. (2012) Development of Ultra-High Erucic Acid Oil in the Industrial Oil Crop Crambe abyssinica. Plant Biotechnology Journal, 10, 862-870. http://dx.doi.org/10.1111/j.1467-7652.2012.00709.x

[22] European Union Strategic Research Agenda (2005) Strategic Research Agenda, Part II: Plant for the Future. Stakeholder Proposal for a Strategic Research Agenda 2005 Including Draft Action Plan 2010.

[23] Artus, N.N. (2006) Arsenic and Cadmium Phytoextraction Potential of Crambe Compared with Indian Mustard. Journal of Plant Nutrition, 29, 667-679. http://dx.doi.org/10.1080/01904160600564444

[24] Paulose, B., Kandasamy, S. and Dhankher, O.P. (2010) Expression Profiling of Crambe abyssinica under Arsenate Stress Identifies Genes and Gene Networks Involved in Arsenic Metabolism and Detoxification. BMC Plant Biology, 10, 108. http://dx.doi.org/10.1186/1471-2229-10-108

[25] Mahmood, T., Islam, K.R. and Muhammad, S. (2007) Toxic Effects of Heavy Metals on Early Growth and Tolerance of Cereal Crops. Pakistan Journal of Botany, 39, 451-462.

[26] Aydinalp, C. and Marinova, S. (2009) The Effects of Heavy Metals on Seed Germination and Plant Growth on Alfalfa Plant (Medicago sativa). Bulgarian Journal of Agricultural Science, 15, 347-350.

[27] Taylor, G.J. and Foy, C.D. (1985) Differential Uptake and Toxicity of Ionic and Chelated Copper in Triticum aestivum. Canadian Journal of Botany, 63, 1271-1275. http://dx.doi.org/10.1139/b85-176

[28] Wheeler, D.M., Power, I.L. and Edmeades, D.C. (1993) Effect of Various Metal Ions on Growth of Two Wheat Lines Known to Differ in Aluminium Tolerance. Plant and Soil, 155-156, 489-492. http://dx.doi.org/10.1007/BF00025090

[29] Li, W., Khan, M.A., Yamaguchi, S. and Kamiya, Y. (2005) Effects of Heavy Metals on Seed Germination and Early Seedling Growth of Arabidopsis thaliana. Plant Growth Regulation, 46, 45-50. http://dx.doi.org/10.1007/s10725-005-6324-2

[30] Shaikh, I.R., Shaikh, P.R., Shaikh, R.A. and Shaikh, A.A. (2013) Phytotoxic Effects of Heavy Metals (Cr, Cd, Mn and $\mathrm{Zn}$ ) on Wheat (Triticum aestivum L.) Seed Germination and Seedlings Growth in Black Cotton Soil of Nanded, India. Research Journal of Chemical Science, 3, 14-23.

[31] Al-Qurainy, F. (2010) Application of Inter Simple Sequence Repeat (ISSR Marker) to Detect Genotoxic Effect of Heavy Metals on Eruca sativa (L.). African Journal of Biotechnology, 9, 467-474.

[32] Freeman, J.L. and Salt, D.E. (2007) The Metal Tolerance Profile of Thlaspi goesingense Is Mimicked in Arabidopsis thaliana Heterologously Expressing Serine Acetyl-Transferase. BMC Plant Biology, 7, 63. http://dx.doi.org/10.1186/1471-2229-7-63

[33] Nasr, N. (2013) Germination and Seedling Growth of Maize (Zea mays L.) Seeds in Toxicity of Aluminum and Nickel. Merit Research Journal of Environmental Science and Toxicology, 1, 110-113.

[34] Heidari, M. and Sarani, S. (2011) Effects of Lead and Cadmium on Seed Germination, Seedling Growth and Antioxidant Enzymes Activities of Mustard (Sinapis arvensis L.). ARPN Journal of Agricultural and Biological Science, 6, 44-47.

[35] Zhao, F.J., Jiang, R.F., Dunham, S.J. and McGrath, S.P. (2006) Cadmium Uptake, Translocation and Tolerance in the Hyperaccumulator Arabidopsis halleri. New Phytologist, 172, 646-654. http://dx.doi.org/10.1111/j.1469-8137.2006.01867.x

[36] Meng de, K., Chen, J. and Yang, Z.M. (2011) Enhancement of Tolerance of Indian Mustard (Brassica juncea) to Mercury by Carbon Monoxide. Journal of Hazardous Materials, 186, 1823-1829. http://dx.doi.org/10.1016/j.jhazmat.2010.12.062

[37] Shen, Q., Jiang, M., Li, H., Che, L.L. and Yang, Z.M. (2011) Expression of a Brassica napus Heme Oxygenase Confers Plant Tolerance to Mercury Toxicity. Plant Cell Environment, 34, 752-763. http://dx.doi.org/10.1111/j.1365-3040.2011.02279.x

[38] Zulfiqar, A., Paulose, B., Chhikara, S. and Dhankher, O.P. (2011) Identifying Genes and Gene Networks Involved in Chromium Metabolism and Detoxification in Crambe abyssinica. Environmental Pollution, 159, 3123-3128. http://dx.doi.org/10.1016/j.envpol.2011.06.027 
Scientific Research Publishing (SCIRP) is one of the largest Open Access journal publishers. It is currently publishing more than 200 open access, online, peer-reviewed journals covering a wide range of academic disciplines. SCIRP serves the worldwide academic communities and contributes to the progress and application of science with its publication.

Other selected journals from SCIRP are listed as below. Submit your manuscript to us via either submit@scirp.org or Online Submission Portal.
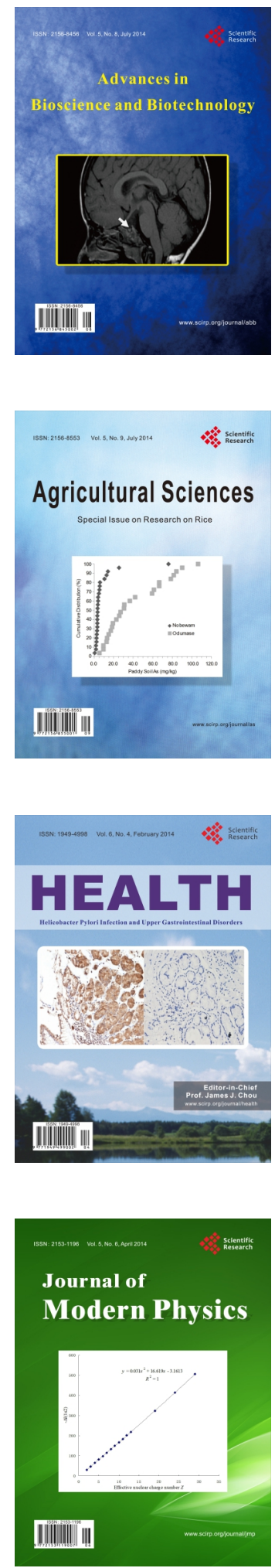
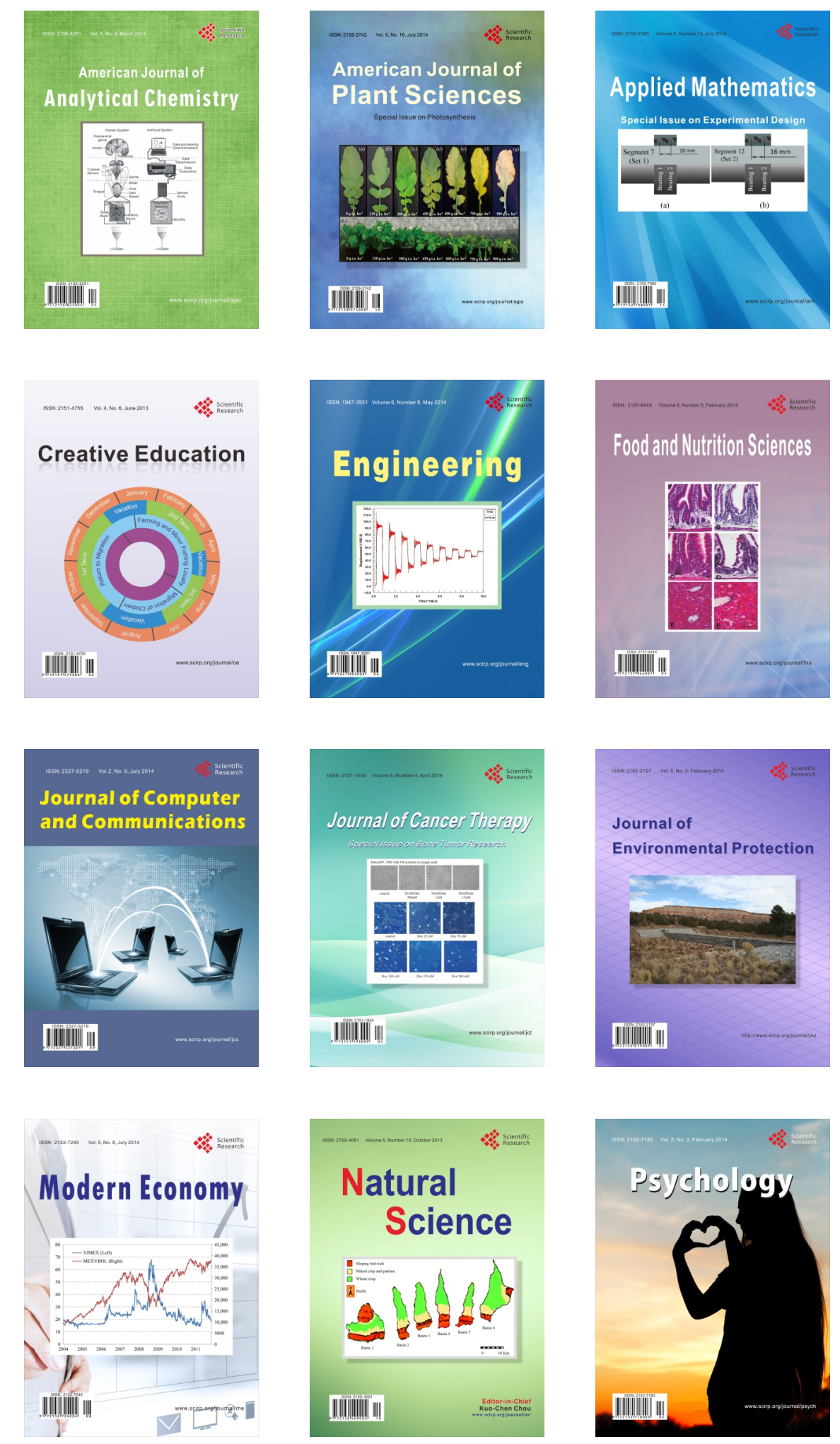